V. K. BHARTI ${ }^{1 *}$ and R. S. SRIVASTAVA ${ }^{1}$

\title{
EFFECTS OF EPIPHYSEAL PROTEINS AND MELATONIN ON THE BLOOD BIOCHEMICAL PARAMETERS OF FLUORIDE-INTOXICATED RATS
}

\author{
Received March 4, 2010.
}

\begin{abstract}
We examined the effects of fluoride intoxication on certain blood plasma biochemical indices in rats. Forty-eight adult female Wistar rats weighing 123-142 g were divided into eight groups: two control groups ( 0 and 28 days) and six experimental groups, namely sham-injected animals (vehicle), those injected with pineal proteins (PP) and melatonin (Mel), intoxicated with fluoride $(\mathrm{F})$, and also $\mathrm{F}+\mathrm{PP}$ and $\mathrm{F}+\mathrm{Mel}$ groups. Fluoride $(150 \mathrm{ppm}$, per os administration with drinking water), melatonin $(10 \mathrm{mg} / \mathrm{kg}$, i.p.), and PP $(100 \mu \mathrm{g} / \mathrm{kg}$, i.p.) were administered daily for 28 days. Blood samples were collected at the end of experiments to estimate plasma $\left[\mathrm{Na}^{+}\right]$and $\left[\mathrm{K}^{+}\right]$, alkaline phosphatase (ALP) activity, and levels of glucose and proteins in different animal groups. The plasma $\left[\mathrm{K}^{+}\right]$and $\left[\mathrm{Na}^{+}\right]$, and ALP activity were significantly $(P<$ $<0.05)$ elevated in F-treated animals, as compared with others. Administration of PP and Mel in F-treated rats caused significant $(P<0.05)$ reduction of $\left[\mathrm{Na}^{+}\right],\left[\mathrm{K}^{+}\right]$, and ALP levels. Interestingly, PP and Mel administrations resulted in noticeable $(P<0.05)$ increases in the plasma glucose level in F-intoxicated animals, as compared to other groups. These findings convincingly indicate that PP and Mel exert ameliorative effects on fluoride-induced adverse changes in certain biochemical parameters in rats.
\end{abstract}

Keywords: fluoride, oxidative stress, plasma biochemical composition, melatonin, pineal proteins, alkaline phosphatase.

\section{INTRODUCTION}

The environment of farm animals (and animals and humans in general) contains a variety of stressors and toxic substances. In farm animals, this can cause reduction of the productivity by affecting a number of physiological functions [1, 2]. Among these stressors, there are nutritional stress, managemental stress, production load, infectious agents, chemical toxicants, etc. $[3,4,5]$. Of particular interest are those associated with oxidative stress (OS), thus causing poor health of the animals. Fluoride is a well-established and extensively known agent, which generates free radicals and induces OS in a variety of animal species [5-8]. It also determines well-identified potential health risk for humans $[9,10]$. Intoxication by fluoride can result from geochemical peculiarities of the environment and/or industrial contamination of the latter.

\footnotetext{
${ }^{1}$ Indian Veterinary Research Institute, Izatnagar, India.

* Present address: Nutrition and Toxicology Laboratory, Defence Institute of High Altitude Research (DIHAR), DRDO, Ministry of Defence, Leh-194101, India.

Correspondence should be addressed to V. K. Bharti

(e-mail: vijaykbharti@rediffmail.com).
}

Antioxidant enzyme activities exhibit endogenous rhythms under normal light/dark conditions. This is true both in terms of their activity and gene expression. These time-related changes suggest that these cycles might be dependent on the circadian melatonin rhythm $[11,12]$. Abolition of the endogenous melatonin cycle by exposure of animals to any toxicity also neutralized the rise in antioxidative enzyme activity.

In the blood and brain of animals, various changes occur after chronic influence of fluoride. These changes include abnormal behavior patterns, altered neuronal and cerebrovascular integrity, and metabolic lesions [13]. Fluoride was shown to inhibit enzymes involved in energy production, membrane-bound ion transport, and neurotransmission [14]. The significance of toxic effects of fluoride on the CNS was confirmed by numerous studies $[7,8]$. Thus, fluoride accumulation leads to cascading effects resulting in negatively altered functions of the brain. However, the toxicity kinetics and pathogenesis of fluoride-induced disorders are still unclear from many aspects.

The pineal gland has been referred to as the epiphysis cerebri, or "parietal eye," and considered 
as "Regulator of Regulators" by virtue of its capability to regulate the functions of other neural and endocrine tissues to maintain homeostasis [15]. This important neuroendocrine structure has a rich supply of adrenergic nerve fibers that greatly influence its secretions. Microscopically, the gland is composed of pinealocytes (neuroendocrine units) and glial cells. It secrets melatonin that intensely affects the serotonin level and, due to this, influences various neuroendocrine functions. Pineal physiology is mostly controlled by noradrenaline released from sympathetic nerves terminating in the gland. Nerve fibers from the hypothalamus project to the superior cervical ganglia, from which post-ganglionic neurons ascend back to the epiphysis [16]. Thus, the epiphyseal functions are to a certain extent similar to those of the adrenal medulla in the sense that the epiphysis transduces signals from the sympathetic nervous system into a hormonal signal. Melatonin is secreted under the control of the suprachiasmatic nuclei of the hypothalamus. Several neural structures have been identified as targets for the effects of melatonin. Numerous physiological, biochemical, and behavioral functions of the organism are significantly controlled by epiphyseal secretions. Pineal gland actions (that have directly been identified) include those led by the ability of epiphyseal secrets to directly neutralize a number of toxic reactants and to stimulate antioxidative enzymes [17]. The epiphysis is able to reduce fluoride-induced OS and adverse biochemical changes via secretion of melatonin; this was demonstrated in a few animal species [7, 18]. It has been stipulated for years that the mammalian epiphysis secrets, besides melatonin, a few biologically active proteins, peptides, and enzymes. These agents are responsible for many physiological roles of the above structure (other than those of melatonin) [19]. Despite of a few studies, the functional role of epiphyseal proteins in the animals has been poorly understood [20-23]. Therefore, our study was taken to know the effects of epiphyseal (pineal) proteins and melatonin in amelioration of $\mathrm{F}^{-}$induced adverse changes in biochemical indices of the blood plasma in rats.

\section{METHODS}

This study was conducted at the Neurophysiology Laboratory of the Division of Physiology and Climatology, Indian Veterinary Research Institute, Izatnagar (Uttar Pradesh), India. All the procedures conducted on the experimental animals were duly approved by the Institutional Animal Ethics Committee (IAEC) and Committee for the Purpose of Control and Supervision of Experiments on Animals (CPCSEA).

Chemicals. The chemicals of the analytical grade used in the study were from Loba Chemie (India); diagnostic kits were procured from Span Diagnostic Ltd (India). Melatonin was procured from Sigma, USA. Epiphyseal proteins obtained from the buffalo (Bubalus bubalis) were produced using an original technique and supplied by the Neurophysiology Laboratory, Division of Physiology and Climatology, IVRI, Izatnagar, India.

Experimental design. The present study was carried out on adult female Wistar rats procured from the Laboratory Animal Resource (LAR) Section of the Institute. Forty-eight sexually mature and healthy female rats (body mass 123 to $142 \mathrm{~g}$ ) were used in the study. Rats on arrival were examined for any abnormality or overt ill health. After a 1-weeklong acclimatization period, they were weighed and randomly assigned into eight groups so as to give initial approximately equal group mean body weights. Treatment groups including doses, route of administration, and treatment duration are shown in Table 1. Rats were housed in polypropylene cages, and rice husk was used as the nesting material. Animal room temperature and relative humidity were set at $21 \pm 2{ }^{\circ} \mathrm{C}$ and $50 \pm 10 \%$, respectively, and lighting was controlled to give $12 \mathrm{~h}$ light/ $12 \mathrm{~h}$ darkness. All the animals had free access to standard laboratory animal diet and clean water, arrangements for which were made in the cages. The animals were checked daily for the health and husbandry conditions.

Before the start of experiment, appropriate doses of fluoride, melatonin, and epiphyseal proteins were optimized in a pilot trial. The fluoride level in drinking water was calculated, and thereafter-required concentration of $\mathrm{F}^{-}$was made by the addition of sodium fluoride daily for 28 days. The dose of epiphyseal proteins and melatonin were calculated based on the body weight and, thereafter, they were dissolved in a suitable vehicle before administration (daily for 28 days). Solutions for administration in experimental animals were prepared daily, to minimize possible instability of the chemicals in the mixture.

Sample collection. Daily observations were taken for behavioral changes and clinical signs of toxicity and mortality, if any, throughout the experimental period. The blood samples were collected through cardiac puncturing under ether anesthesia on day zero 


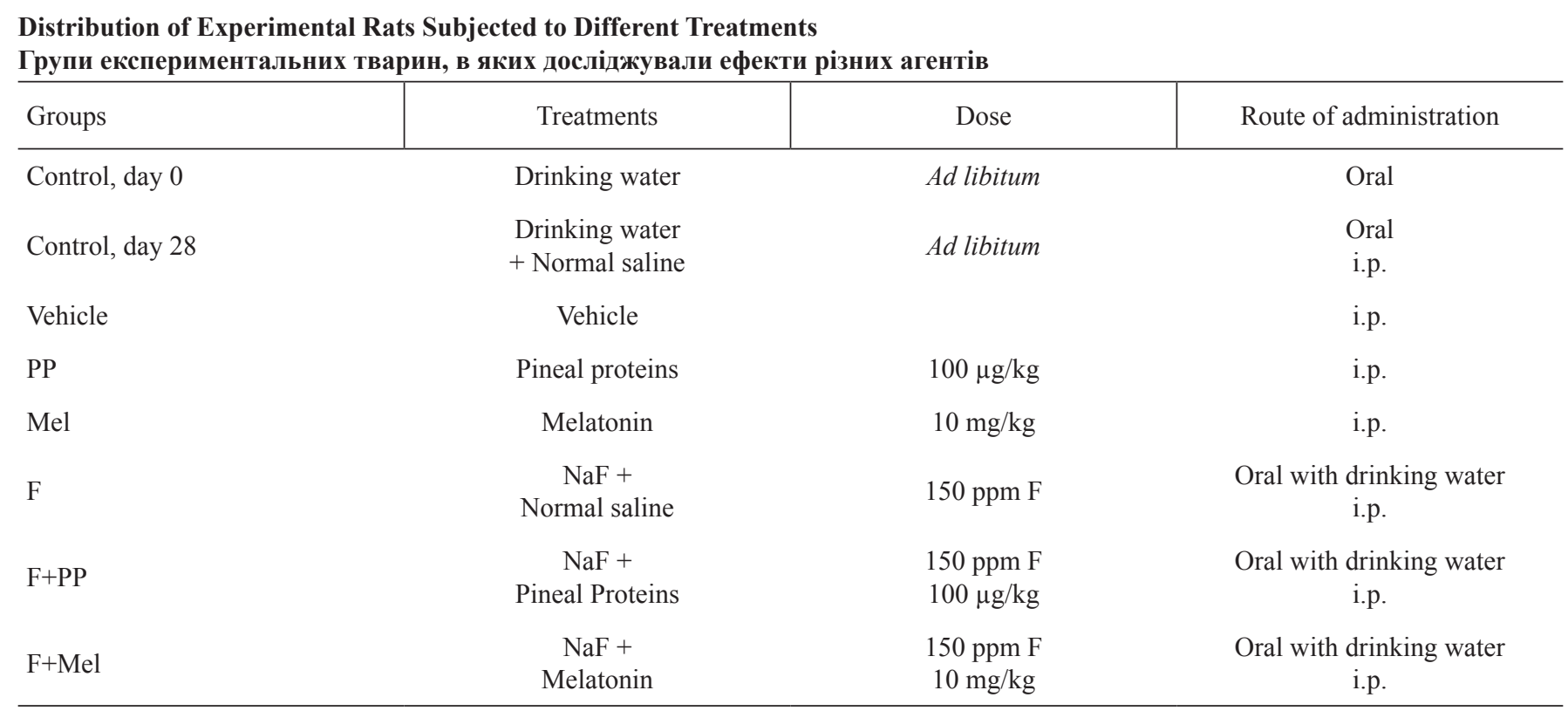

and at the end of the experiment (day 28). Thereafter, the plasma was separated from the blood samples for biochemical analysis.

Analytical procedures. Plasma samples were separated and stored at $-20^{\circ} \mathrm{C}$ for the following biochemical estimations. Blood glucose was estimated using Kits (Span Diagnostics Ltd, India) with the help of a semi-auto analyzer (ERBA CHEM-5 Plus). Total serum protein and albumin were estimated by using diagnostic kits (Span Diagnostics Ltd) with the help of the above analyzer. Plasma sodium and potassium concentrations were estimated simultaneously by the method of Oser [24] using a flame photometer.

The plasma alkaline phosphatase (ALP) activity was assayed using the respective diagnostic kits (Span Diagnostics Ltd.), and OD was read using a spectrophotometer (ECIL, India).

Statistical analysis. Differences between groups were statistically analyzed by one-way ANOVA, and the differences between the means of groups were separated by least significant difference (LSD) test. Values of $P<0.05$ were regarded as significant. A computer program (SPSS 10.01, SPSS Inc., USA) was used for statistical analysis.

\section{RESULTS}

Invariably, all the data were compared and discussed with the control data (day 28) value and also with the initial control (day 0), if mentioned. Fluoride intoxication carried out in the above-described mode induced significant elevations of the $\mathrm{Na}^{+}$and $\mathrm{K}^{+}$ levels in the blood plasma of experimental rats. A rise in the $\mathrm{Na}^{+}$level, as compared with the control (day $28)$, was relatively moderate $(21.8 \%)$, while a rise in the $\mathrm{K}^{+}$level was dramatic $(51.5 \%$, Fig. 1A, B). Introduction of $\mathrm{NaF}$ during 28 days also resulted in a highly significant (nearly twofold) increase in the ALP activity, i.e., in the activity of the enzyme considered the marker of fluoride toxicosis and bone pathology (C). At the same time, fluoride intoxication induced practically no change in the protein level in the plasma (D); a rather mild increase in the level of glucose was insignificant (E).

The treatment of fluoride-intoxicated rats with melatonin and pineal proteins produced from the epiphyses of the Buffalo exerted beneficial effects on the blood plasma levels of $\mathrm{K}^{+}$and $\mathrm{Na}^{+}$increased under the influence of $\mathrm{F}^{-}$. The shifts of the $\mathrm{Na}^{+}$concentration in the respective groups $(\mathrm{F}+\mathrm{Mel}$ and $\mathrm{F}+\mathrm{PP})$ were about two times smaller than those in the untreated fluoride group (Fig. 1A); thus, the levels of $\mathrm{Na}^{+}$and $\mathrm{K}^{+}$in Meland PP-treated animals were quite comparable with the norm (B). The activity of ALP was also considerably normalized under the influence of Mel and PP; shifts of this index in the corresponding groups were about three times smaller than that in the fluoride-intoxicated group (C). The fact that the content of plasma proteins somewhat increased in the F+PP group and dropped in the $\mathrm{F}+\mathrm{Mel}$ group, may be, deserves attention (D). At the same time, it is necessary to emphasize that 

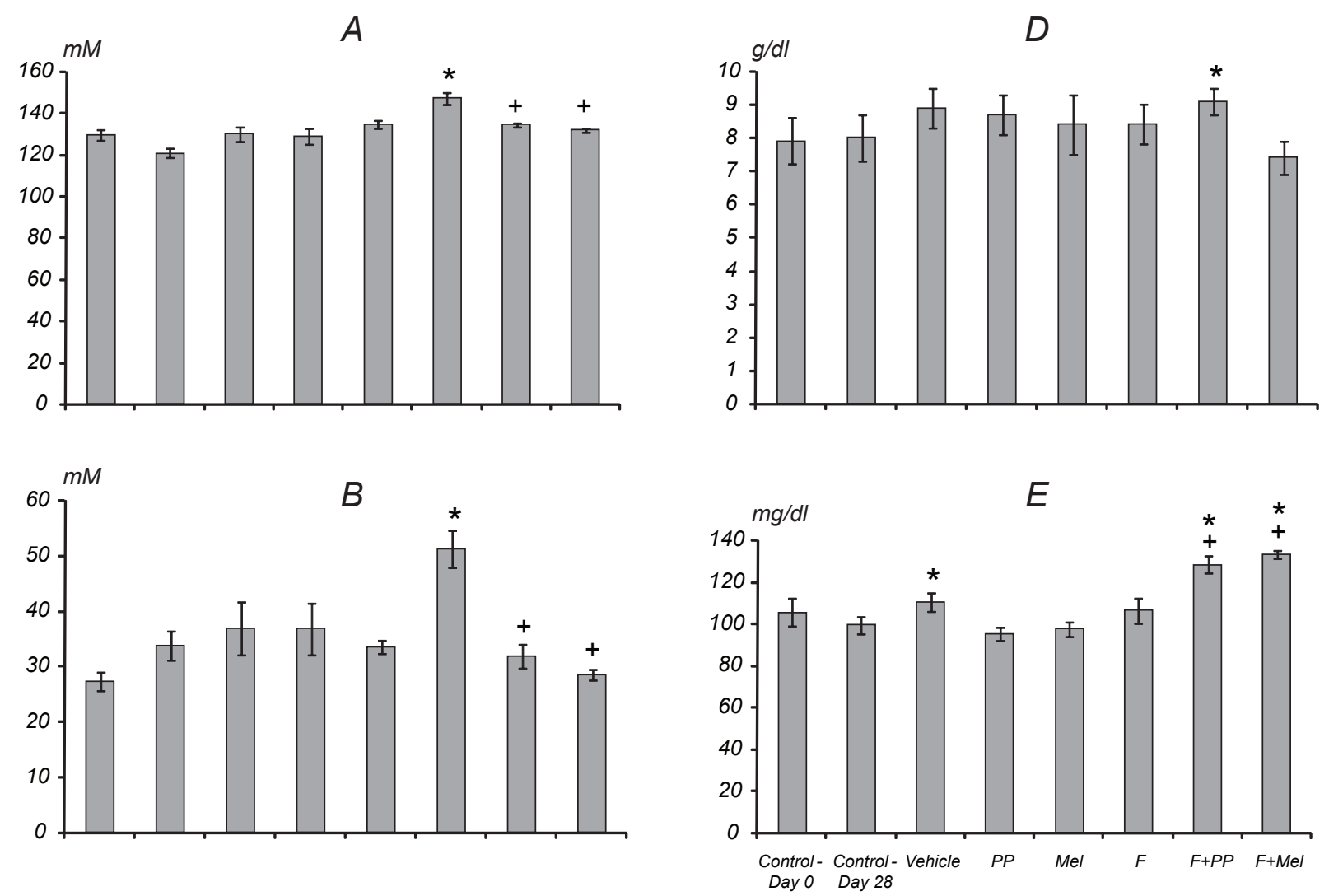

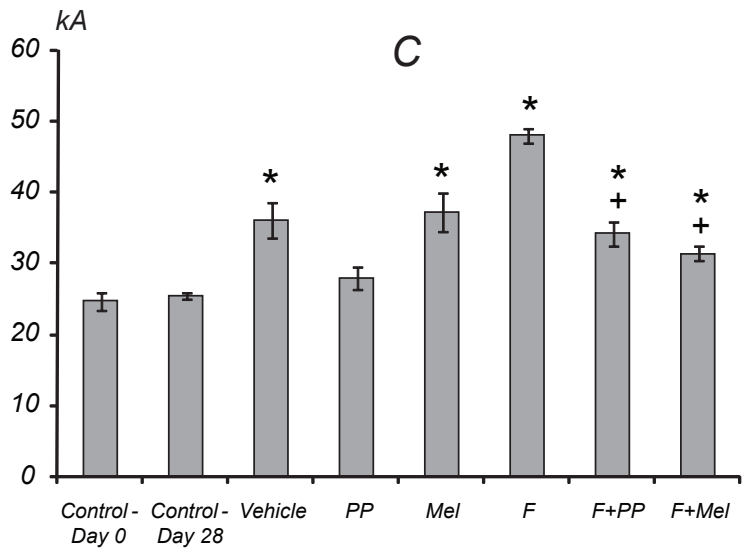

treatment with both $\mathrm{Mel}$ and PP resulted in significant (about 30\%) increases in the glucose level in the respective fluoride-intoxicated groups, as compared with the normal one; rises, as compared with the $\mathrm{F}^{-}$ group, were also significant (E).

Isolated introductions of pineal proteins and melatonin exerted no significant effects on the great majority of the biochemical indices measured in the blood of experimental rats (Fig. 1A-E). Some rise in the ALP activity in the PP-treated group was an exception. It should be mentioned that the above- mentioned index also somewhat increased in the vehicle-treated group (C).

\section{DISCUSSION}

Fluoride was found to exert diverse effects on a number of cellular functions and those of the physiological systems including inhibition of a variety of enzymes and induction of hypocalcemia and hyperkalemia $[25,26]$. We did not estimate the 
$\mathrm{Ca}^{2+}$ level in the blood plasma in the present study, but intense hyperkalemia and moderate hypernatremia were recorded in fluoride-treated rats. Therefore, our findings confirm the earlier observations of Varner et al., [25] that high fluoride causes hyperkalemia, hypernatremia, and a considerable imbalance in blood electrolyte homeostasis. These facts indicate that blood plasma mineral imbalance and, respectively, that in the extracellular milieu in the CNS constitutes an important link in the disorders during fluorideinduced OS in animals. The above electrolyte shifts are capable of changing the transmembrane potential in the cells, including CNS neurons, and of modulating the process of neurotransmission. Therefore, high fluoride intake may have important adverse effects on the brain functions. Verna and Sherlin [27] also reported higher sodium and potassium concentrations in the serum of F-treated animals than those in the vehicle control. It should be taken into consideration that the found rises in the $\mathrm{Na}^{+}$and $\mathrm{K}^{+}$levels can provide a serious shift in the osmolarity of the blood plasma (with the respective effects on the cells, including those of the CNS). The above authors [25, 27] further reported certain amelioration of NaF-induced effects on the levels of the above cations due to administration of either vitamins $\mathrm{C}$ and $\mathrm{B}$ or a combination of vitamins $\mathrm{C}+\mathrm{D}+\mathrm{E}$. Thus, a beneficial role of antioxidants on OSinduced changes in the contents of $\mathrm{Na}^{+}$and $\mathrm{K}^{+}$in the blood is obvious.

Changes in the behavior patterns, in particular hyperactivity and cognitive deficits, were described in experiments on animals (rats) with $\mathrm{F}^{-}$intoxication. Fluoride is accumulated in different regions of the brain, especially in the hippocampus and epiphysis $[28,29]$. Excessive fluoride decreased the level of 5-hydroxy indole acetic acid and increased that of noradrenaline in the rat brain. These changes decreased secretion of melatonin.

Alkaline phosphatase (ALP) is the marker enzyme with respect to fluoride toxicosis and osteal pathology. An increase in plasma ALP activity in fluoride-treated animals was reported $[4,26,30]$ in different animals. The increased activity of plasma ALP in our study may be due to the effect of fluoride intoxication on bone and other connective tissues. Insult of fluoride to bones may increase the osteoclastic activity, which initiates a repair response, and this is related to the high ALP activity observed in NaF-treated rats [26, 31]. Comparable observations were also reported by Teotia and Teotia [32].

It should be mentioned that melatonin administration alone exerts a contradictory effect, as compared to that of pineal proteins alone, as the latter did not alter ALP activity with respect to the control animals. However, combinations of $\mathrm{F}^{-}$intoxication with pineal proteins and melatonin considerably decreased the dramatically F-increased plasma ALP activity. Recently, it was observed that melatonin can remove $\mathrm{F}^{-}$ions from the cells via GSH mediation and also that it controls the osteoclastic activities [8, 23].

Fluoride intoxication caused a marginal elevation in the plasma glucose level, as compared to the control animals (it should be mentioned that vehicle administration also exerted a comparable effect with this respect). The glucose level plays a role in determining the oxidative status; therefore, a balance between oxidative and antioxidant processes appears to be sensitive to the glucose levels with moderate elevations of the latter affecting the oxidative status [33]. In our study, it was interesting to notice rather strong effects of melatonin and pineal proteins on the plasma glucose level in fluoride-intoxicated animals.

The cerebral epiphysis is a fundamental neuroendocrine effector playing an exclusively important role in the circadian system. The production of the main pineal hormone melatonin and, probably, of other epiphyseal secrets (proteins) is regulated in mammals by retinal photoreceptors, the hypothalamic suprachiasmatic nucleus, and the sympathetic nervous system. The effects of epiphyseal extracts are rather multifacial [34], and a part of them are not explainable on the basis of the content of melatonin and other pineal indoles.

The glucose level plays a role in determining the oxidative status; therefore, the balance between oxidative and antioxidant processes appears to be sensitive to the above parameter, and moderate elevations of glucose should be considered a beneficial effect with respect to the state of oxidative stress [33]. Thus, some elevations of blood glucose are positive factors helping animals to meet increased energy requires and to combat oxidative stress. At the same time, melatonin and pineal proteins administered alone demonstrated no effect on the glucose level. These findings clearly indicate that these agents per se have at least a rather limited effect on glucose metabolism in rats. The data regarding the effects of melatonin and pineal proteins on this process are, in general, scarce. We are unable to compare in detail our findings with others obtained under dissimilar experimental conditions. A significant increase in the plasma glucose level in rats was reported by Bojkova 
et al. [35]. This contradictory result may be due to a difference in the dose and or age of experimental rats.

In our study, both fluoride and melatonin/ pineal proteins did not induce any changes in the level of plasma proteins. Thus, it may be assumed that administration of high doses of fluoride for a relatively short duration exerts no effect on plasma proteins in female rats. Our results also demonstrated that pineal proteins or melatonin do not influence the plasma protein level, which allows us to suggest that antioxidant supplementation to animals may have no effect on their normal protein metabolism. These findings agree with the data of Ogeturk et al. [36], as they also reported insignificant changes in the plasma protein level after melatonin treatment in rats. However, the treatment with pineal proteins brought increases in plasma proteins in goats [37] and guinea pigs [38], mostly due to high globulin levels. These discrepancies partly may be attributed to species-related variation. Since these findings were made under different experimental conditions, we are not in a position to compare our results with these reports. To find out specific effects of pineal proteins and melatonin on metabolism of proteins, additional detailed studies are needed.

There is no doubt that the available results, which often differ significantly from one another, depend on a number of factors. Among the latter, there are the levels of fluoride, species of experimental animals, sex of the animals, hind of the tissue examined, mode and time of exposure to fluoride, nutritional status, and techniques for biochemical assay [39-42].

Thus, our study demonstrated that introductions of melatonin and pineal proteins exert noticeable beneficial effects on the plasma ion composition significantly disturbed by high-fluoride intoxication; these agents to a great extent correct the fluidelectrolyte imbalance. These findings provide valuable information on the action of antioxidants on plasma electrolytes and widen scope for the effects of antioxidants. Therefore, impaired behavior and brain functions resulting from fluoride-induced changes in the $\mathrm{Na}^{+}$and $\mathrm{K}^{+}$contents can be at least partly restored by administration of melatonin and pineal proteins.

Our study elucidated that pineal proteins produced from the Buffalo epiphysis do not induce any toxic influence on the plasma biochemical parameters investigated and, thus, can be used as a therapeutic agent in effective preventing oxidative stress. Naturally, our findings require further exploration.
Acknowledgment. Research grant in the shape of Institute Senior Research Fellowship to the first author and facilities provided by Indian Veterinary Research Institute for conducting this study is duly acknowledged. We also acknowledge the tireless efforts of our lab and animal shed assistants.

\section{B. К. Бхарті ${ }^{1}$, Р. С. Шрівастава}

\section{ВПЛИВ СЕКРЕТІВ ЕПІФІЗА (ПІНЕАЛЬНИХ ПРОТЕЇНІВ I МЕЛАТОНІНУ) НА БІОХІМІЧНІ ПАРАМЕТРИ КРОВІ ЩУРІВ В УМОВАХ ІНТОКСИКАЦІЇ ФТОРИДОМ}

${ }^{1}$ Індійський ветеринарний дослідницький інститут, Ізатнагар (Індія).

P е 3 ю м е

Вивчали впливи інтоксикації фторидом на деякі біохімічні показники плазми крові щурів. 48 дорослих самиць щурів лінії Вістар (маса тіла 123-142 г) були розділені на вісім груп: дві контрольні (виміри на початку експерименту та на 28-й день) і шість експериментальних, тваринам яких протягом 28 днів ін'єкували розчинники (плацебо-контроль), пінеальні протеїни (ПП, 100 мгк/кг, внутрішньоочеревинно) i мелатонін (Мел, 10 мг/кг, внутрішньоочеревинно), а також уводили $\mathrm{NaF}$ (150 ppm) з питною водою. У сьомій та восьмій групах досліджували ефекти $\mathrm{F}+$ ПП і $\mathrm{F}+$ Мел. Наприкінці експерименту відбирали проби крові для оцінки концентрацій глюкози, плазмових протеїнів, $\left[\mathrm{Na}^{+}\right]$, $\left[K^{+}\right]$та активності лужної фосфатази (ЛФ) у різних групах тварин. Концентрації $\mathrm{K}^{+}, \mathrm{Na}^{+}$та активність ЛФ у групі інтоксикованих фторидом щурів були істотно $(P<0.05)$ збільшені. Паралельне введення ПП і Мел тваринам, які отримували фторид, викликало істотне $(P<0.05)$ зниження концентрацій $\mathrm{Na}^{+}$та $\mathrm{K}^{+}$, а також активності ЛФ. Цікаво відзначити, що введення ПП і Мел призводило до помітного $(P<0.05)$ підвищення рівня глюкози в плазмі крові інтоксикованих фторидом тварин порівняно з таким у щурів інших груп. Ці дані переконливо свідчать про те, що ПП і Мел впливають нормалізуючим чином на індуковані фторидом негативні зрушення певних біохімічних параметрів у щурів.

\section{REFERENCES}

1. R. J. Collier, D. K. Beede, W. W. Thatcher, et al., "Influences of environment and its modification on dairy animal health and production," J. Dairy Sci., 65, 2213-2227 (1982).

2. J. W. West, "Effects of heat stress on production of dairy cattle," J. Dairy Sci., 86, 2131-2144 (2003).

3. R. K. Ringer, "Effects on domestic animals," in: Ecotoxicology and Climate, J. A. Bourdeau, W. K. Haines, and C. R. K. Murti (eds.), John Wiley and Sons Ltd. (1989), pp. 225-232.

4. V. K. Bharti, "Fluorosis: A serious health problem of domestic animals," Livestock Int., 10, No. 12, 17-20 (2006). 
5. R. Rzeuski, D. Chlubek, and Z. Machoy, "Interactions between fluoride and biological free-radical reactions," Fluoride, 31, 43-45 (1998).

6. X. Y. Guo, G. F. Sun, and Y. C. Sun, "Oxidative stress from fluoride induced hepatotoxicity in rats," Fluoride, 36, No. 1, 25-29 (2003).

7. S. L. Chawla, R. Yadav, D. Shah, and M. V. Rao, "Protective action of melatonin against fluoride-induced hepatotoxicity in adult female mice," Fluoride, 41, No. 1, 44-51 (2008).

8. V. K. Bharti and R. S. Srivastava, "Fluoride-induced oxidative stress in rat's brain and its amelioration by buffalo (Bubalus bubalis) pineal proteins and melatonin," Biol. Trace Elem. Res., 130, No. 2, 131-140 (2009).

9. P. Celi, A. D. Trana, and A. Quaranta, "Metabolic profile and oxidative status in goats during the peripartum period," Austral. J. Exp. Agriculture, 48, No. 7, 1004-1008 (2008).

10. W.H.O. Environmental Health Criteria, 36: Fluorine and Fluoride. WHO. Geneva. (1984).

11. C. Rodriguez, J. C. Mayo, R. M. Sainz, et al., "Regulation of antioxidant enzymes: a significant role for melatonin," $J$. Pineal Res., 36, No. 1, 1-9 (2004).

12. M. Diaz-Munoz, R. Hernandez-Munoz, J. Suarez, et al., "Daynight cycle of lipid peroxidation in rat cerebral cortex and their relationship to the glutathione cycle and superoxide dismutase activity," Neuroscience, 16, 859-863 (1985).

13. P. J. Mullenix, P. K. Denbesten, A. Schunior, and W. J. Kernan, "Neurotoxicity of sodium fluoride in rats," Neurotoxicol. Teratol., 17, 169-177 (1995).

14. M. L. Vani and K. P. Reddy, "Effects of fluoride accumulation on some enzymes of brain and gastrocnemius muscle of mice," Fluoride, 33, 17-26 (2000).

15. H. J. Romijn, "The pineal: a tranquillizing organ," Life Sci., 23, 2257-2274 (1978).

16. P. Voisin, M. G. Harrington, J. L. Weller, et al., "Noradrenergic control of the synthesis of two rat pineal proteins," Brain Res., 517, Nos. 1/2, 25-34 (1990).

17. R. J. Reiter, D. Melchiorri, E. Sewerynek, and B. Poeggler, "A review of the evidence supporting melatonin's role as an antioxidant," J. Pineal Res., 23, 43-50 (1995).

18. R. J. Reiter, "Pineal melatonin: cell biology of its synthesis and of its physiological interactions," Endocrinol. Rev., 12, 151-180 (1991).

19. D. E. Blask, M. K. Vaughan, and R. J. Reiter, in: The Pineal Gland, R. Relkin (ed.), Elsevier, Amsterdam (1983), pp. 201224.

20. M. Tandon, R. S. Srivastava, S. K. Meur, and M. Saini, "Proteins and peptides present in pineal gland and other brain structures of buffaloes," Indian J. Animal Sci., 76 (5), 383394 (2006).

21. V. Sejian, Studies on Pineal-Adrenal Relationship in Goats (Capra hircus) Under Thermal Stress, Ph.D. Thesis, Indian Veterinary Research Institute, Izatnagar, India (2006).

22. V. K. Bharti and R. S. Srivastava, "Pineal proteins up-regulate specific antioxidant defense systems in the brain," Oxid. Med. Cell. Longev., 2, No. 2, 88-92 (2009).

23. V. K. Bharti and R. S. Srivastava, "Protective role of pineal proteins at different dose level on fluoride-induced changes in plasma biochemicals and blood antioxidants enzymes in rats," Biol. Trace Elem. Res., DOI: 10.1007/s12011-010-8733-y (2010).
24. B. L. Oser, Hawk's Physiological Chemistry, McGraw-Hill Book Co., New York (1965).

25. J. A. Varner, K. F. Jenson, W. Horvath, and R. L. Isaacson, "Chronic administration of aluminum fluoride or sodium fluoride to rats in drinking water: alteration in neuronal and cerebrovascular integrity," Brain Res., 784, 284-298 (1998).

26. V. K. Bharti, M. Gupta, and D. Lall, "Ameliorative effects of boron on serum profile in buffalo (Bubalus bubalis) fed high fluoride ration," Trop. Anim. Health Prod., 40, No. 2, 111-116 (2008).

27. R. J. Verma and D. M. Guna Sherlin, "Sodium fluoride-induced hypoproteinemia and hypoglycemia in parental and F (1)generation rats and amelioration by vitamins," Food Chem. Toxicol., 40, No. 12, 1781- 1788 (2002).

28. L. I. Ding, "The nervous systemic complications of chronic fluorosis," Chinese J. Endemiology, 2, 97-98 (1983).

29. J. A. Luke, The Effect of Fluoride on the Physiology of the Pineal Gland, Ph. D. Thesis, School of Biological Sciences, University of Surrey, England (1997).

30. D. Shanthakumari, S. Srinivasalu, and S. Subramanian, "Effects of fluoride intoxication on lipid peroxidation and antioxidant status in experimental rats," Toxicology, 204, 219228 (2004).

31. S. M. Farley, J. E. Wrgedal, L. Smith, et al., "Fluoride therapy for osteoporosis: Characterization of the skeletal response by serial measurement of serum alkaline phosphatase activity," Metabolism, 36, 211-218 (1987).

32. S. P. S. Teotia and M. Teotia, "Endemic fluoride: bone and teeth-update," Indian J. Environmental Toxicol., 1, 1 (1991).

33. V. Menon, M. Ram, J. Dorn, et al., "Oxidative stress and glucose levels in a population-based sample," Diabetic Med., 21, 1346-1352 (2004).

34. B. Benson and I. Ebels, "Pineal peptides," J. Neural Transm., Suppl., 13, 157-173 (1978).

35. B. Bojková, M. Marková, E. Ahlersová, et al., "Metabolic effects of prolonged melatonin administration and short-term fasting in laboratory rats," Acta Vet. Brno, 75, 21-32 (2006).

36. M. Ogeturk, I. Kus, A. Kavakli, et al., "Effects of melatonin on carbon tetrachloride-induced changes in rat serum," J. Physiol. Biochem., 60, 205-210 (2004).

37. V. Sejian and R. S. Srivastava, "Effects of melatonin on adrenal cortical functions of Indian goats under thermal stress," Veterinary Med. Int., 2010, 1-6.DOI:10.4061/2010/348919 (2010).

38. M. Ramasamy, Studies on Bubaline Pineal Proteins/Peptides Below $20 \mathrm{kDa}$ and their Immunopotentiation in Guinea Pigs, $\mathrm{Ph}$. D. Thesis, Indian Veterinary Research Institute, Izatnagar, India (2006).

39. D. Swarup, S. Dey, S. R. C. Patra, et al., "Clinicoepidemiological observations of industrial bovine fluorosis in India," Indian J. Animal Sci., 71, 1111-1115 (2001).

40. D. Chlubek, H. E. Grucka, R. Polaniak, et al., "Activity of pancreatic antioxidant enzymes and malondialdehyde concentrations in rats with hyperglycemia caused by fluoride intoxication," J. Trace Element Med. Biol., 17, No. 1, 57-60 (2003).

41. V. K. Bharti, M. Gupta, D. Lall, and V. Kapoor, "Effect of boron on haemogram and biochemical profile of urine in buffalo calves fed a high fluoride ration," Fluoride, 40, No. 4, 238-243 (2007).

42. A. K. Susheela, "Fluorosis management programme in India," Curr. Sci., 77, No. 10, 1050-1056 (1999). 